\title{
The public rights to the sidewalk in a smart city framework: The case study of Surabaya City
}

\author{
Hak publik atas trotoar dalam bingkai tatanan kota pintar: \\ Studi kasus Kota Surabaya
}

\author{
Siti Aminah \\ Department of Political Sciences, Faculty of Social and Political Sciences, \\ Universitas Airlangga \\ Address: Jalan Dharmawangsa Dalam, Airlangga, Surabaya, East Java, Indonesia 60286 \\ E-mail: siti.aminah@fisip.unair.ac.id
}

Article History: Received 19 May 2020; Accepted 9 April 2021; Published Online 20 April 2021

\begin{abstract}
The sidewalk transformation in Surabaya smart city system encountered critical problem for pedestrians because transformation as a public space has reduced citizens' rights to the city. Dominant forces tend to subordinate street vendors or Pedagang Kaki Lima (PKL), who require public space. The city or urban government produces pedestrians as public spaces to support the 'Smart City' concept. This study explores the government's ability to guarantee citizens' rights to the city. In addition, this study seeks to observe the process of public space transformation in cities that implement smart city systems and analyze spatial street vendors' practices in the pedestrian space. This research applies the right to cities and public space from a Marxian spatial perspective. This research is a case study that uses a qualitative method and interpretive analysis. Research findings indicate pedestrians' paradox due to the government's dispossession process to protect pedestrians through 'furniturization' policies that reduce smart city implementation. In conclusion, there are dynamics of spatial practice and social expression as sidewalk problems. The smart city system's implementation causes the loss of fulfillment of the poor and street vendors' needs and rights to participate inclusively in the social and political process in managing the city's public spaces.
\end{abstract}

Keywords: city rights; sidewalk; public space; smart city; street vendors

\begin{abstract}
Abstrak
Perubahan eksistensi trotoar di Kota Surabaya yang menerapkan tatanan kota pintar (smart city) menghadapi problematika kritis dari perubahan eksistensi trotoar sebagai ruang publik yang telah mengurangi hak warga atas kota. Pedagang kaki lima (PKL) yang melakukan praktik spasial di trotoar menjadi pihak yang disubordinasi oleh kekuatan dominan. Trotoar diproduksi sebagai ruang publik oleh pemerintah kota untuk mendukung berjalannya tatanan kota pintar. Studi ini mengeksplorasi bagaimana ruang trotoar yang dikontrol oleh pemerintah menjamin hak warga atas kota. Studi ini bertujuan untuk menjelaskan proses terjadinya transformasi ruang publik trotoar pada kota yang menerapkan tatanan smart city, dan menganalisis praktik spasial PKL di ruang trotoar. Teori yang digunakan adalah hak atas kota dan ruang publik dari perspektif spasial Marxian. Penelitian ini adalah studi kasus yang menggunakan analisis kualitatif dengan metode analisis interpretif. Temuan penelitian menunjukkan bahwa eksistensi trotoar bersifat paradoksal dan ada proses pemindahan dan perampasan ruang-ruang trotoar oleh pemerintah untuk melindungi pejalan kaki melalui kebijakan furniturisasi yang mengurangi konten kota pintar. Studi ini menyimpulkan bahwa dalam trotoar ada dinamika praktik spasial dan ekspresi sosial. Implementasi tatanan kota pintar menyebabkan hilangnya pemenuhan kebutuhan dan hak PKL dan warga miskin kota untuk berperan serta secara inklusif dalam proses sosial dan politik pengelolaan ruang publik kota.
\end{abstract}

Kata kunci: hak atas kota; trotoar; ruang publik; kota pintar; pedagang kaki lima

\section{Introduction}

The transformation of public spaces function in big cities contains socio-economic and political dynamics. Public spaces and pedestrians represent various power relations in society. In the pedestrian area, citizens participated in political and social life. Pedestrians also become a space to talk about 
rights issues (Lefebvre 1991) and society's dominant forces. Examining spatial practices of citizens, especially street vendors or Pedagang Kaki Lima (PKL), reveals the following things: 1) the relationship between the power that represents the state and the representatives of society, 2) sidewalk function transformation into subordinate spaces as a result of economic structural change and urbanization, and 3 ) the loss of citizens' rights to the city. The spatial practices of citizens are determined by architects' and policymakers' roles in designing public spaces (Van Deusen 2002). Public spaces produced by space designers (architects and local government) defined public space's form and function; however, the development of pedestrians lacked consideration over public rights over the space; thus, public spaces were solely aimed at addressing the city landscape, economic, social, and cultural purposes.

On the other hand, public rights to cities are far from accommodated into the policy makers' agenda. In today's ideal urban development planning, pedestrians are associated with the concept of the modern and smart city. The upholding of the smart city normatively supports the development of a supra modern city. The supra modern city has become a battleground for various market forces and the socio-political process of placing the icon of consumerism. It causes many urban problems that lead to increased inequality, alienation, and intolerance in public spaces (Keymolen \& Voorwinden 2019, Von Schonfeld $\&$ Bertolini 2016). In the context of a smart city, the government supervise and control urban public spaces, including the sidewalk. The program is designed to promote and build citizen awareness of pedestrians' substance that prioritizes environmentally friendly way of life to improve the quality of life in general (Allwinkle \& Cruickshank 2011, Locton 2011).

The narrative of the smart city cannot be separated from the global development of supra modern cities. The smart city concept's implementation ensures the running of the interconnecting elements of people's daily lives. Public space is changing rapidly in cities that have experienced a process of de-industrialization and economic globalization. Achmad et al. (2018) state that a smart city is a city whose city management system is automatically able to notify: 1) that an urban problem is occurring (notified by sensors installed in the city), 2) that an urban problem will arise (notified by the sensor and prediction systems), and 3) has urban management systems capable of providing automatic (enabled by the actuator system) or non-automatic action proposals to solve the problem. Cohen (2012) divides the smart city into six dimensions: smart economy, smart mobility, smart environment, smart people, smart living, and smart governance.

In the smart city concept, information and communication technology becomes the economic power of urban growth and changes the way cities compete (Bakici et al. 2012). Around the world, cities are competing to be the best models of sustainable development. Concerning pedestrians, smart cities seek to support socio-systemic activities with policy considerations that are beneficial from a social perspective and a cultural, aesthetic, and economic perspective (McCord \& Becker 2019). The public sphere's transformation into a meeting place for politics and culture, social and individual spheres, and expressive and instrumental space. The pedestrian public space is one of the cases representing a public space that is transforming that function. New strategies and innovative practices strengthen urban public spaces and culture (Winkowska et al. 2019).

In the context of smart cities, public space has become a subordinated space. Alteration in public space value is adjusted to accommodate dominant groups' interests, the formal power (government), and the economic and political sectors (Lefebvre 1991). As the dominant group, the government designs public spaces such as roads, open spaces, and pedestrian areas with little accommodation to urban poor and street vendors. The use of public space is closer to non-commercial purposes, which affects street vendors' spatial practice on the pedestrian. Increasing urbanization from rural to urban areas has resulted in a growing number of urban areas. As one of the big cities in Indonesia, Surabaya had a rapid population growth rate of 2.07 percent in 2019, while the growth in the previous year was 0.64 percent. Badan Pusat Statistik Surabaya report that, in 2019, Surabaya's population was 3.15 million. It has encouraged the Surabaya City Government to organize the city and procure new public spaces with a sustainable development perspective. In turn, it increases government power over public spaces. 
Meanwhile, managing public spaces to accommodate different groups' interest is not an easy task for the Surabaya government. There are various groups and public space users that the Surabaya government policy cannot fully benefit from. In the morning, street vendors use parts of pedestrian zones to sell secondhand goods while they turn into parking areas, food, and coffee markets at night, frequently used by people from different social classes and urban areas. Pedestrian zones play a significant role in creating social interactions and high value for residents, and street vendors' presence has become an integral part of such space. The pedestrian zone is a public space where social, economic, and cultural activities develop.

The development of public spaces in Surabaya contains ideological problems and spatial practices of citizens; however, the marginalized group's interest was not always in line with the approach implemented by government and public space planners. In reality, many functions attached to pedestrianization cannot be implemented even though the spatial development of Surabaya has progressed beautifully. Surabaya has developed broad pedestrian zones with supporting facilities such as bollards, flowerpots, telephone pole bins, traffic signs, electricity poles, and trees along with the smart city paradigm. Despite its beauty, the city government is still associated with group interest in building and organizing pedestrian zones, which hinders citizens' rights as pedestrians. This study reveals the problem of pedestrian zone development from public space and rights to the city.

The construction of pedestrian zones in the world's major cities applies the smart city concept. Repko \& DeBroux (2012) argue that pedestrian zones' construction cannot be separated from the smart city concept's integrative framework. The existence of pedestrian zones on either side of the highway embodies the relationship between mobility and public space and tension. The pedestrian zone symbolizes the struggle to accommodate the functions of mobility, economic function (efficient and fast), and socio-political, which can lead to contestation and negotiation (Agyeman \& Zavetovski 2015, Mehta 2013, Nagati \& Stryker 2016) as well as the function of an extension of the transportation system.

There are an evolution and transformation of the pedestrian zone's function (Ehrenfeucht \& Sideris 2007). The study shows a potential conflict over the function of the pedestrian zone between the government and the community, especially street vendors. Daniere and Douglass (2009) stated that street vendors do not have access to pedestrian zones because they are not involved in the planning process of public space design or public policy. Pedestrian zones as public spaces in urban areas are in trade, mobility, and social life (Duneier 1999, Goldstein 2016, Kim 2015). White (2000) emphasized that the party that manages public spaces such as malls, plazas, and parks will be highly associated with conflict and negotiation between the government and the community. The situation results from the struggle over the functions of these spaces. An example of pedestrian zone surveillance is Ho Chi Minh City (Vietnam) which is heavily guarded by the city government so that its use ensures flexibility for pedestrians. Pedestrian zone transformation as public spaces in Surabaya with a smart city arrangement has not been widely studied. In addition, this study also analyzes the spatial practices of street vendors in pedestrian spaces.

\section{Research Method}

Surabaya was chosen as a research locus based on an empirical and theoretical approach. Between 2010 and 2018, Surabaya built 45.118 meters of pedestrian zones in 91 road points. Data from the Public Works Office, Highways of Surabaya, recorded that, in 2017, the government had built pedestrian zones during the first semester of 2017 for 5.225.67 meters and three meters wide across all areas of Surabaya (www.news.detik.com). Previously, the pedestrian area was used for two- wheeled vehicles and parking, also as an area for street vendors. Another group, such as for cars/ bicycle parking and street vendors, open their stalls in pedestrian spaces. Activity in the pedestrian zones causes inconvenience to pedestrian mobility.

The pedestrian zones have undergone a socio-political transformation. The main road pedestrian zones are clear from street vendors (Jalan Gemblongan, Jalan Tunjungan, Jalan Pemuda, Basuki Rahmat, Urip Sumoharjo, Raya Darmo) and comfortable for pedestrians because of the wide distance from the 
road. Second, pedestrian zones in Surabaya as public spaces are supervised by intensive surveillance through security guards to neutralize their economic function whereby street vendors and motorized vehicles park. In other words, pedestrian zones have become a repressive space due to the security guard's involvement daily. Third, pedestrian zones in Surabaya tend to transform into supra modern big cities. They create a connection between mobility and public space and increase tension between the government and city residents.

From the theoretical approach, Surabaya city pedestrian zones are related to the normative function of pedestrians. These areas symbolize the struggle to accommodate public spaces' mobility functions, including its users' social interactions (Agyeman \& Zavetovski 2015; Mehta 2013). Pedestrian zones determine the future of urban developments; they remain a diverse area with complex use (Jacobs 1961). In this argument, pedestrian zones' critical function is to provide security and space for contact between residents. Likewise, Mehta (2013) argued that roads, including pedestrian zones, as public spaces become a space of interaction between residents because roads are classic social public spaces in the urban system. Carr et al. (1992) argue that public space planning should be integrated with public life. Ideal planning should be guided with high consideration of the design process by involving citizens in the management. The public space must be adjusted to its unique social and environmental context.

Data were collected through interviews with pedestrians, street vendors, policymakers such as city government and regional people's representatives'assembly, and law enforcers such as security guards. Interviews were designed in structured and unstructured conversations to generate verbal data (Given 2008). Researchers conducted discussions about eviction and supervision of street vendors by the municipal government when utilizing the pedestrian zones based on the implementation of Regional Policy Number 9 of 2014. The pedestrian areas' observation method was carried out in the morning and evening when security guards disciplined street vendors. This study took pictures of pedestrian zones and their facilities used by street vendors. Observations were made on the pedestrian zones in the post-eviction period. The attitudes and behavior of street vendors, when they were disciplined were analyzed for nonverbal cues. This research employed the internet to collect, sort, store, and/or analyze the collected information. Researchers employed a qualitative data analysis method, which involves standard features of data. Interview and observation processes were carried out by coding, using writing to analyze, develop concepts, and analyze connections to the literature used in this study. The overall data were interpreted from the perspective of the neo-Marxian space.

\section{Results and Discussion}

\section{Pedestrian conditions in the city of Surabaya}

The existence of pedestrian zones in Surabaya cannot be separated from its historical development as a city of industry, trade, education, government, and culture. It influences the Surabaya Government to continuously protect the pedestrian zones from potential users such as street vendors who appear to affect the urbanization explosion. The Surabaya Government recorded that, in 2017, security officials disciplined 14,883 street vendors and eliminated the rights of street vendors in Surabaya. The Head of the Surabaya Government Cooperatives and Micro-enterprises Office stated:

\footnotetext{
"It is not an easy problem to make arrangements for street vendors: however, that does not mean it cannot be done. Like what has been done by the Surabaya government when orderly arranged street vendors. At that time, in various areas in Surabaya, there were many street vendors. They mostly sell in pedestrian areas like pedestrian zones, parks, roadsides and in other locations. Furthermore, it is said that they usually sell in places that are prohibited, such as pedestrian areas, roadsides and so on."
}

Based on observations of street vendors who interact with customers in Perak Barat Street, Perak Timur Street, Rajawali Street, Veteran Street, Ngaglik Street, Gembong Street, Kapasan Street, Indrapura Street, HR. Muhamad Street, Mayejn Sungkono Street, and Dharmawangsa Street, it is pointed out that 
street vendors who sell food often serve customers without disrupting the flow of pedestrians. The area has no trash cans, bollards, traffic signs, or trees. This pedestrian space creates a comfortable waiting room for street vendors along the pedestrian zone. If there is a crowd at certain times, such as with the end of school time, pedestrians and street vendors maneuver to walk in a line. Street vendors selling food are also responsive to pedestrian flow and moving paths by reducing impeding this. Meanwhile, a member of Surabaya Regional People's Representative Council for Commission C in the Development Sector of the (DPRD) explained that:

\begin{abstract}
"A number of pedestrian projects are considered to reduce the side of the roadside. Members of Commission C of the Surabaya DPRD said that there are many pedestrian projects that diminish the size of roadside, thus causing roads in Surabaya to become narrow. This condition has resulted in higher traffic congestion on a number of roads in Surabaya. Instead of adjusting the road to pedestrian projects, the pedestrian area is the one which should have been adjusted to the road. Should the road be arranged according to the project, this will lead to conflict with the Road Ownership Area Law, which is under the domain of the police. In addition, Surabaya traffic is getting higher because the road is getting narrower. Pedestrian zones have reduced the road width, it should be returned to normal".
\end{abstract}

\title{
A different opinion was expressed by a member of Commission C of Surabaya DPRD.
}

\begin{abstract}
"The construction of pedestrian zones which is currently being carried out by the Surabaya City Government is not in accordance with the needs of the residents. Construction of pedestrian zones by increasing the width that takes up the road body so that it reduces the traffic jams of vehicles is not appropriate. Many pedestrian zones were built which were extended to two to three meters, even on small roads. It is less effective because it reduces vehicle lanes and causes congestion. What the people of Surabaya need is the provision of adequate road capacity in the form of road widening."
\end{abstract}

Figure 1 show space being fought over between hotel owners, shop owners, residents, and street vendors. There is no regulation regarding the designation of public space. Street vendors can put their stalls in front of residents' houses, as well as shop owners can put their merchandise on the pedestrian zones. There are also pedestrian areas where no street vendors' spatial practices are allowed, as shown by the sign-in Figure 1. There is no coexistence between street vendors and non-government- managed public spaces. In addition, there is no consistent reproduction of pedestrian public spaces, both on the main and suburban roads for street vendors. In Tunjungan Street and Pemuda Street, there is a bollard with a disabled-friendly design. The government can adequately monitor bollards installation on the main road. For pedestrian zones outside the main road, the installation of bollards interferes with the mobility of pedestrians and persons with disabilities. Installation of bollards and other accessories in public pedestrian zones cannot be uniformed. Every pedestrian space is related to the social and economic environment.

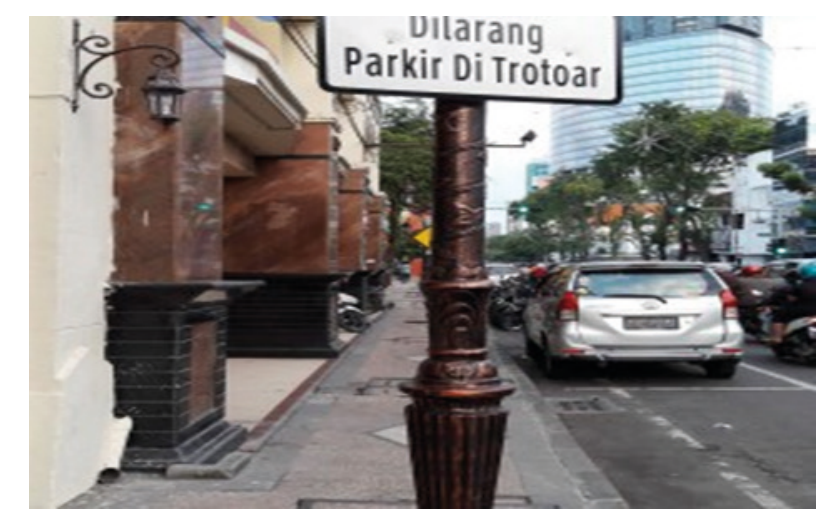

Figure 1.

Jalan Tunjungan sidewalk

Source: Center for Security and Welfare Studies (2018) 
Jalan Tunjungan is one of the historical sites in the trade sector and is a pivot road that connects main roads in Surabaya. The pedestrian zone widening on the right and left sides of the road has reduced citizens' rights to the city. The width of the road has decreased due to the widening of the pedestrian areas. Likewise, the pedestrian zones along Blauran Street have reduced residents' rights to pedestrian public spaces. As shown in Figure 2, in general, there are no street vendors along the road, only a few small stalls that survive and do not disturb the pedestrian zones.

The pedestrian zones along Kapasari and Ngaglik Street are under intensive surveillance, although there is no large-scale trading activity in the area. In Figure 3, there are many shops located close to densely populated villages. Residents frequently use the pedestrian zone as a place to trade. Pedestrian zones located in large-scale trade complexes, public and social facilities (train stations, schools, trade centers) tend to be used by street vendors. These spaces are closely monitored by security officials, which causes such space to lose its democratic character. There has been no negotiation of interests between officers and users even though there are spaces not monitored by the authorities, such as in Gembong Street.

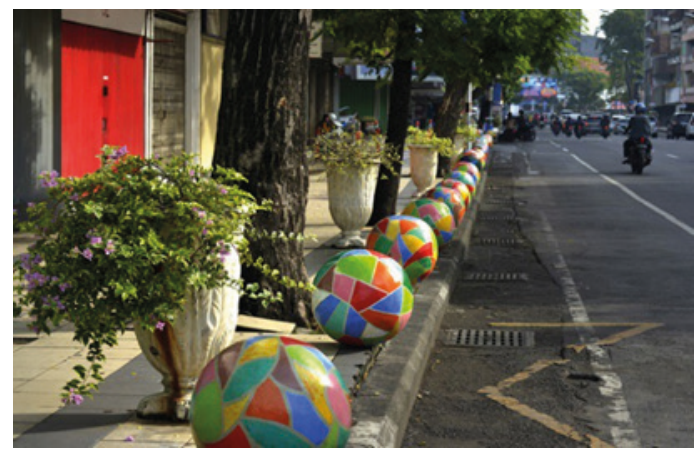

Figure 2.

Jalan Blauran sidewalk

Source: Center for Security and Welfare Studies (2018)

The pedestrian zone along Gemblongan Street is an old trading area that is one of the access points to the main roads of Surabaya. In Figure 4, the pedestrian zones on Jalan Gemblongan are used by shop owners who sell household furniture. The pedestrian zone is a capitalist extension and an icon of the smart city that inherits the site of the old city. Interestingly, residents' spatial practices are guaranteed to meet their consumptive needs, shopping for household furniture. However, not all pedestrian zones in a commercial environment are comfortable for pedestrians. Several pedestrian zones have changed the function of being a government monitoring area for citizens who violate pedestrian space designation. Pedestrian space has become an ambulatory practice of the city government for pedestrian zones along Darmo Main Road, Dr. Soetomo Street, Basuki Rahmat Street, Mayjen Sungkono Street others. In Table 1, it is explained that the Surabaya City Government has built pedestrian zones on various roads to facilitate pedestrian users.

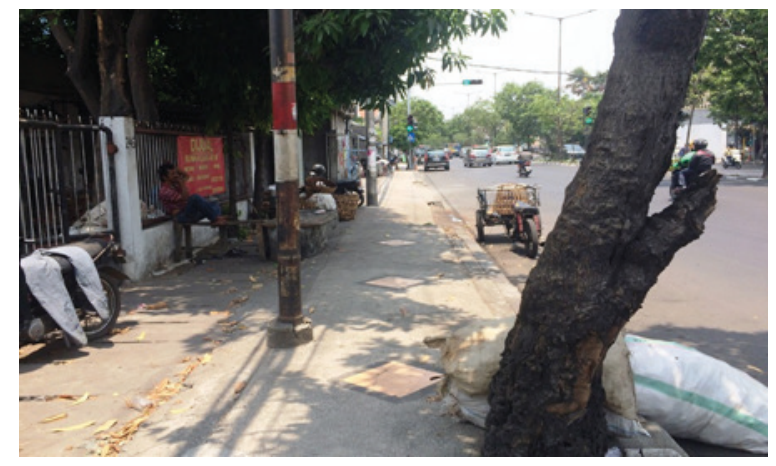

Figure 3.

Kapasari sidewalk

Source: Center for Security and Welfare Studies (CSWS) 2018 
Along with developing a supra modern city, Surabaya can build pedestrian zones using the citizens' spatial perspective. The pedestrian public space will not become a space for repression and government power enforcement. The pedestrian space also does not permit a space for public rebellion due to security officials' surveillance daily. Pedestrian public spaces are multifunctional spaces that allow all citizens to access and use them for spatial practices and ideological concerns.

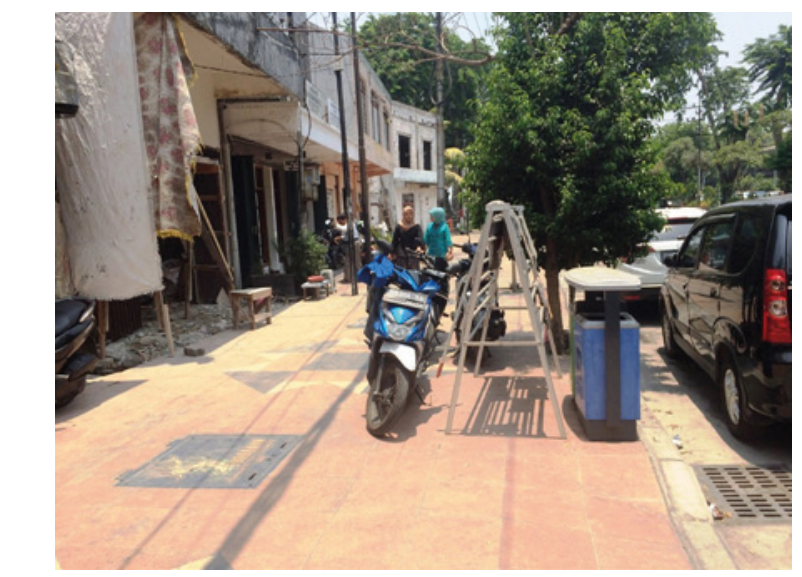

Figure 4.

Jalan Gemblongan sidewalk

Source: Center for Security and Welfare Studies 2018

Economic practices carried out by street vendors remove street vendors' rights over cities. This indicates public spaces are not entirely accessible to fulfill the public interest. In Surabaya, pedestrian zones become a separator between road space for vehicles and pedestrian mobility. Thus, pedestrian zones are equipped with various facilities to support their functions for safety and comfort. Moreover, the pedestrian zones have become a repressive and undemocratic space because it has shifted away from its public character as an urban space for social interaction. As imagined by Lefebvre (1996), the urban public sphere is a place to accommodate the increasing effects of commodification and capitalism, which eventually led to increasing spatial inequality in cities around the world over the last two centuries. On top of that, pedestrian zones are a form of capitalist practices, even though they are relevant for cities to accommodate many urbanites and respond to the challenges of capitalism urbanization, especially the informal economy sector.

Table 1.

Pedestrian zone development in Surabaya

\begin{tabular}{|c|c|}
\hline Location & $\begin{array}{l}\text { Length (in } \\
\text { meter) }\end{array}$ \\
\hline Demak-Jalan Solotigo Street & 335 \\
\hline Semarang Street (western side)- & 486 \\
\hline $\begin{array}{l}\text { Margorukun Street up to Tembok Dukuh Street } \\
\text { Southern Side of HR Muhammad Street }\end{array}$ & 300 \\
\hline Pandegiling Street & 670 \\
\hline Airlangga Street & 345 \\
\hline Nginden Street & 410 \\
\hline Kartini Street - Diponegoro Street & 400 \\
\hline Perak Barat Street & 330 \\
\hline Jemursari Street & 220 \\
\hline Kertajaya Indah Street & 333 \\
\hline Kendangsari Street & 407 \\
\hline Northern Side of Mayjend Sungkono Street & 203 \\
\hline Southern Side of Dharmahusada Indah Street & 250.6 \\
\hline Dr Soetomo Street & 285 \\
\hline Dharmawangsa Street & 250 \\
\hline
\end{tabular}

Source: Pemerintah Kota Surabaya (2018) 
The pedestrian zones have undergone a transformation from a neutral public space to street vendors, codified in the Perda. Street vendors are not allowed to take advantage of the sidewalk. The characteristics of the pedestrian zone have also turned into a modern city icon that is beautiful and humane for pedestrians. The pedestrian spaces that exist along with the neighborhood of shops, hospitals, luxury housing (upscale), and offices already protect and provide a sense of security and comfort for pedestrians. Various accessories that support its primary function for pedestrians are placed in the pedestrian zone. This is an indication of the revitalization of the pedestrian zones to complement the smart city identity.

Table 2.

Surabaya pedestrian zones development 2010-2018

\begin{tabular}{lr}
\hline \multicolumn{1}{c}{ Year } & Length $\left(\mathbf{m}^{\mathbf{2}}\right)$ \\
\hline 2010 & 9.942 \\
2011 & 2.185 .7 \\
2012 & 4.669 .60 \\
2013 & 4.558 \\
2014 & 4689 \\
2015 & 9.446 \\
2016 & 9.627 .80 \\
2017 & 2.419 \\
2018 (July) & 52.763 \\
\hline
\end{tabular}

Source: Efendi (2018) processed data

As shown in Table 2, pedestrian zones in Surabaya have been expanded. There is also an expansion of the pedestrian area that narrows the road's public spaces on Jalan Tunjungan because the pedestrian area is widened to about six meters. The sidewalk expansion eliminates public space for parking for two-wheeled and four-wheeled vehicles and causes traffic jams in the morning, afternoon, and evening. Consequently, several business establishments (shops) are closed due to a lack of visitors who have difficulty parking their vehicles. The condition of the existing pedestrian zones in Surabaya is designed to protect pedestrians. According to the Head of the Surabaya Public Works Office:

"If the construction of a sidewalk project takes up the roadside because the initial design of the
sidewalk project was based on consultation from World Bank, we adjust the width according to
World Bank advice, expecting support from them. The initial concept the project was to make
pedestrians comfortable, so that they were interested in using public transportation. At least, if
people feel comfortable and want to use public transportation, the number of private vehicles can
be reduced".

The pedestrianization expansion on Jalan Tunjungan cleared street vendors along the road and no longer provided parking spaces for motorized vehicles. In Jalan Kupang Mulyo I, Sukomanunggal, street vendors occupying a building above the canal caused them to be evicted by the sub-district officials. According to regional regulation, those who use pedestrian areas for other means, such as street vendors, have violated regional regulation number 9 of 2014 concerning Space for Street Vendors in Shopping Centers and Office Centers in Surabaya City. Based on this regulation, street vendors' existence has caused traffic jams and created a waste problem. Given the regulation, the eviction by the officials was correct.

The modern development of Surabaya had become a paradox when street vendors were orderly arranged. On the one hand, the government represented by security officials should enforce the regional regulation to prevent street vendors' spatial practice. On the other hand, Surabaya's rapid economic growth cannot be separated from street vendors' contribution and enormous capitalist forces. The presence of street vendors is part of the urbanization process, and pedestrian zones have become part of capitalism. No matter how small the contribution of street vendors to Surabaya's economic growth, their presence is represented by the breadwinners who sell used books and magazines, used clothes, new goods, and also beggars, while they have to deal with the security forces daily. 
Conflicts of interest to regulate the spatial practices of urban residents are not easy to solve. The regulation of street vendors' spatial practices also aims to promote pedestrians' areas to gain comfort and safety. Members of the Surabaya City Council understood these sidewalk spatial practices in the 2014-2019 period to protect sidewalk spatial practices and led to ideological practices. The government has intensively developed and widened pedestrian zones to realize a beautiful, clean, comfortable city clear of street vendors.

In the context of a smart city, pedestrian zones are produced and reproduced by the city government to provide safety and comfort to pedestrians. Such development is also in line with the rapidly increasing population to create a beautiful, clean and comfortable city for all residents. Based on the Central Bureau of Statistics (2016) data, the total area of Surabaya in 2016 was $326.81 \mathrm{~km} 2$, and the total population was 3,057,766 people until the end of August 2017. Therefore extending pedestrian zones to protect pedestrians was regarded as necessary.

\section{Commodification and conversion of pedestrian zone functions by residents of the Surabaya City}

According to Lefebvre \& Harvey, the concept of the right to the city is suitable to frame the reality of street vendors' struggle to gain their right to access public pedestrian spaces. Street vendors uses the pedestrian zone as an area to place their stalls to sell food and drinks, sell used goods, and more. In this case, street vendors were unable to fight against the dominant power of the city government. Therefore, street vendors have become a subordinate class that is unable to participate inclusively in the political process, especially in planning the pedestrian spaces development. The street vendors' struggle to gain access to pedestrian zones cannot be achieved through revolution. However, capitalism, which is embedded in the life of street vendors, is a method for them to get their rights over the city. The circumstances influenced the government to design a sophisticated pedestrian zone with supporting facilities, which causes these to become an exclusive space and no longer multi-functional for people in urban areas.

Studies in various countries show pedestrian zones as public spaces face various challenges because of their various functions, which are not solely for pedestrian mobility but also other public means. As a public space, the pedestrian zone becomes a meeting area for interaction between residents. There are public rights, political space, and habitable space in the pedestrian zone, and a space for trade (Agyeman \& Zavetovski 2015; Madanipour et al. 2013). Ehrenfeucht and Sideris (2007) studied pedestrian zones in five cities in the United States: Boston, Los Angeles, New York, Miami, and Seattle. In pedestrian zones, there is confusion arises because of the characteristics of them as public spaces. With these characteristics, pedestrian zones carry ambiguous boundaries on their public status, competition for particular uses from street vendors, and government control. Pedestrian zone as a public space is in the dynamics of negotiation and conflict between users and potential users. Lefebvre (1991) addressed that society's spatial practice in urban space is the right of citizens to the city.

This study shows that pedestrianization gives the impression of environmentally friendly and pedestrianfriendly space from the bright city perspective. The existing pedestrian zones in public facilities such as hospitals, offices, shops, schools show spatial practices that support the relationship between social groups and environmental aspects. However, social groups from low-income populations will use the pedestrian zone as space to trade and fulfill their daily needs. This spatial practice was attacked by neoliberal groups who requested the city government to control the pedestrian zone's economic activities. Thus, they are no longer functioned as trading places to meet the working class's needs but are designed and constructed to be clear from street vendors. In Harvey's logic, this kind of pedestrianization proves the government's strength in practicing predatory politics and depriving the public of groups of the urban poor who use the pedestrian zones to earn money. 
According to the public space theory, the presence of street vendors on the pedestrian zones is interpreted as an indication of the city government's inability, especially public space development policy planners and architects, to accommodate the diverse interests of citizens in pedestrian zones. City planners cannot accurately describe residents' spatial practices on pedestrian zones and failed to draw upon such spaces' added value.

Pedestrian zones as public spaces have an essential meaning for residents in general. The informal economic activity in the pedestrian zone is inherent in the life of the urban poor. They maintain economic security and stability through informality. In the process of informality, there is a process of commodification. This means that government officials are closely guarded, but other parties also rent that space for informal economic activities. In Surabaya, this can be seen in the changes in pedestrian space functions from time to time. In the morning, the pedestrian area is clear from street vendors, while at night, it transforms into a coffee shop, unattended by the authorities. This is part of the process of commodification of pedestrian spaces as opposed to public spaces codification.

Meanwhile, street vendors' restructuration is highly associated with political means. As a result of development, the character of cities has constantly changed. Capitalist forces also have been integrated with city life, which could lead the city to a crisis. The power of capitalism is inevitable, yet, capitalism has changed the face and existence of urban spaces in Surabaya. This is the concern of Smith and Low (2006) that, in the era of global economic integration, public spaces at different scales (roads, pedestrian zones, parks, malls, plazas) always contain tension between involved parties with its conflict of interest according to the power of each group.

In terms of spatial practice and the Theory of Right to Cities, the intensive supervision of pedestrian zones by security officials can be interpreted as a strategy to protect public space from reinforcing the concept of a smart city. Nevertheless, the pedestrian zone also contains the concept of public rights, where street vendors are part of an informal economy. With this supervision, the government has created a space that places street vendors into a subordinated position, which further reinforced the government's spatial practice. The government also issued Regional Regulation Number 9 of 2014, which does not accommodate the urban poor's needs. The regulation has prevented them from using pedestrian zones as the government has clarified the smart city arrangement that has changed the function of pedestrianization into a practice of space codification and application.

As a result of public spaces' personal and illegal commodification, government officials operate in exercising their authority. This causes pedestrian zones to switch functions, leading to controversial and conflictual relations between street vendors and security officials. Government authorities have restricted people's accessibility to use public pedestrian zones. The government has also made regulations imposing access restrictions for specific categories of people who use the public space. Street vendors use pedestrian zones or roads to earn income and social support and strive for a better life. Therefore, the government should not intensively supervise the pedestrian zones through the security officials, and they should instead pay attention to accommodate the life of the community who seek life in this pedestrian space. Therefore, they are not positioned in a violent public space.

\section{Pedestrian zones serve as spatial and social spaces for city residents}

The government's policy in developing pedestrian zones with various facilities shows that neither the government nor society has used a spatial perspective to produce public spaces. Soja (2010) analyzes that public spaces in urban areas should emphasize the spatial perspective. The social aspect of public space development should be taken into account. There is no public space that is socially neutral. Soja supplemented the arguments from Lefebvre \& Harvey about citizen's inseparable rights to the city. Designing public spaces should pay attention to spatial design aspects and the social aspects of those spaces. Every new public space that is built and repaired has a considerable impact on others' daily lives. On the one hand, the installation of chairs and other facilities increases pedestrian convenience yet reduces the pavement's substance. 
The opinion, as mentioned earlier, strengthens the concept of the Right to City by Lefebvre, Harvey, Soja, and other spatial academics. The presence of pedestrian zones is not only a struggle to eliminate alienation from citizens to public spaces; it is also a method to fulfill citizens' rights. Therefore, citizens are integrated into a network of social connections. Citizens' rights to pedestrian zones are part of citizens' rights to cities. In claiming their rights to the city, residents can also use pedestrian space as their social right. There is a social significance of the public sphere managed by the government and the private sector. Therefore, removing street vendors from the pedestrian space is an action that can lead to resistance from them. In a theoretical frame, public spaces in urban areas result from two aspects of development planning, namely social space and spatial space. Both aspects are the result of urbanism and capitalism. The inevitable effect of urbanization and the rapid flow of capitalism can be ended through the urban revolution (Harvey 2008). According to Harvey: "The right to cities is much more than individual freedom to access urban resources." The right to the city provides citizens the right to change themselves by changing the city. Furthermore, it is a general right, not entitled to individuals, because the transformation is highly dependent on collective force to reshape the urbanization process. Harvey argues that the freedom to create and rebuild cities and people is one of the most valuable human rights. According to Harvey and Lefebvre, the presence of broad pedestrian zones and their facilities can be interpreted as removing citizens' rights to the city, eliminating public rights to public spaces.

The existence of cities is also influenced by urbanization (population and capital). In the cycle of capitalism, cities around the world require capital to produce surplus products. In Harvey's (2008) analysis, the relationship between this type of urbanization and capitalism is two-way: "capitalism continues to produce the surplus products that urbanization needs. In the contrary, capitalism requires urbanization to absorb the excess products that it continues to production cycle." They strive for tangible improvements to produce stronger communities and better conditions for all members of society and future generations. Urbanization has become capitalistic and has become an instrument in the hands of capitalists and a significant feature of the capitalism cycle.

Furthermore, city life is a revolutionary battleground daily. Space domination originated from the social relations of capitalist production. Urban space and cities' existence results from capitalist production processes (Castells 1979, Harvey 2008). Space is a political interest because it is a medium, instrument, the purpose of a struggle, and conflict (Lefebvre 1991). In the space contestation, we acknowledge the dominant space and the dominated space. Castells (1977) argues that the city contains an ideological dimension and a collective reproduction of labor because a city is an area that runs a capitalist system. Public spaces in urban areas result from a plan that determines the spatial practices of communities in public spaces.

The study of Lefebvre (1991) states that the state and the capitalist system regulate and rationalize the space for social production and the reproduction of social space. Space is a social and political product and, therefore, contains political interests (Lefebvre 1991). As a political product, space is the result of a strategy that contradicts representation, appreciation, and practices following the socio-cultural model, the special interests of groups, and certain social classes' position. This happens because the capitalist mode of production produces a specific space; the revolutionary strategy must create another mode of generating space, which, according to Lefebvre, can be done by collectively regaining control of the city (Lefebvre 1991) and by taking back and liberating everyday life, which is highly impossible except in the non-capitalist mode of production.

Not only function as physical infrastructure, but pedestrian space in urban areas also reflects the city's existence and stakeholders' conflicts. The situation shows the domination over space that is associated with the social relations of capitalist production. The diverse use of public spaces is an indicator of the balance between the value of utilization and space exchange value. White (2001) concluded that the greater the number of prominent features in a public space, the more people are attracted to come and use such space; the public space that attracts the most people is the space that can be used as a 
gathering place accessible for visitors. White also describes cities as inherently messy places, but human interaction and commerce activities take place on the streets, including in the pedestrian areas. The activity creates an attractive environment for the road user.

The pedestrian zone as a public space has a competitive nature for its users: as a space for interaction, public domain, political space, livable space, and as a space for commerce (Agyeman \& Zavetovski 2015; Madanipour et al. 2014). Research conducted by Nagati and Stryker (2016) revealed that pedestrian zones are a place for the informal sector economic activities of street vendors in Cairo. The existence of street vendors' existence of spatial practices has led to competition among stakeholders in the pedestrian zone. Bandyopadhyay (2017) found that pedestrian space describes the real collective life in an urban system.

In the History of the Right to the City, in Henri Lefebvre's (1967) version, all citizens without exception are rightful to obtain their rights in gaining quality and benefits of city life. Lefebvre emphasizes the nature of social to spatial relations and avoids ideological claims. Meanwhile, for David Harvey, the city's right is about the working class's strength, people of color, immigrants, youth, and all those who are committed to creating a democratic society. This refers to a condition where all city residents have the capacity and power to make decisions that affect and benefit their lives. Meanwhile, the practice of controlling street vendors on pedestrian zones is also acknowledged as part of social drama (as concluded by Soja, who conducted a dialectic analysis of the spatial concept of Foucault and Lefevbre). During control from security officials, field observation reveals that officers who carried out the control only act as a formality. The street vendors-free pedestrian zone is an attempt to propose a socio-political innovation by the Government of Surabaya in developing pedestrian space. It was said that, after the Satpol PP moved to order another pedestrian space, the street vendors returned to occupy the pedestrian zone.

\section{Conclusion}

As a public space, pedestrian zones are part of the reality of cities that undergo capital and population urbanization. Pedestrian zones are not a suitable place to exercise government dominance, not to mention political subjects being monitored by the government. As a public space, the existence of pedestrian zones $\mathrm{s}$ is paradoxical as an entirely public space. Non-pedestrians are allowed to be in the pedestrian zone as long as they are not street vendors. There is a process of moving and seizing pedestrian spaces by the government to protect pedestrians through furniture nation policies that reduce smart city content. Within the pedestrian zone, there are dynamics of spatial practice and social expression. The city approach's right is not regulated through regional regulation, resulting in the loss of protection of the spatial practices of street vendors in pedestrian areas.

In an intelligent city order, the concept of a neoliberal economy becomes the dominant feature, yet it does not mean that the neoliberal economy always promotes capitalist interests. The implementation of smart cities should emphasize meeting citizens' needs and rights with all services provided by the government. Therefore, citizens' rights to the city can also be realized by inclusive participation of citizens in the social and political processes of managing the city's public spaces.

Citizens' right to pedestrian public spaces is a separate concept from a smart city. Urban policies and pedestrian public spaces' design are implemented in an undemocratic manner, which excludes street vendors' participation. This is to create beautiful and clean cities that prioritize large and formal business needs. Therefore, street vendors' right to city pedestrian zones can become a reality of urban, industrial, and socio-cultural civilization. The public's right to the city becomes a marker of supra modern city life that guarantees justice. The city's right is not a political hope but a social right for all citizens to obtain justice for the citizens' place. Finally, there is no longer politicization to create a sustainable city for pedestrians. 


\section{References}

Achmad KA, Nugroho LE, Djunaedi A, \& Widyawan (2018) Smart city readiness based on smart city council's readiness framework. International Journal of Electrical and Computer Engineering 8 (1):271-279.

Agyeman J \& Zavestoski S (2015) Incomplete Streets: Processes, Practices, and Possibilities. Oxon: Routledge.

Allwinkle S \& Cruickshank P (2011) Creating smarter cities: An overview. Journal of Urban Technology 18 (2). https://doi.org/10.1080/10630732.2011.601103.

BPS (2016) Surabaya dalam Angka. Kota Surabaya: BPS.

Bakici T, Almirall E, \& Wareham J (2012) A smart city initiative: The case of Barcelona. Journal of the Knowledge Economy 4 (2):135-148.

Bandyopadhyay R (2017) Obstruction: Counter-pedestrianism and trajectories of an infrastructure public. Decision 44:121-132. https://doi.org/10.1007/s40622-017-0155-7.

Carr S, Francis M, Riviin L, \& Stone AM (1992) Publik Space. Cambridge: Cambridge University Press.

Castells M (1979) The Urban Question: A Marxist Approach (Translated by Alan Shendan). Cambridge: The MIT Press.

Center for Security and Welfare Studies (CSWS) (2018) Problematika Pembangunan Infrastruktur Publik di Surabaya. Surabaya: CSWS FISIP UNAIR. Unpublished.

Cohen B (2012) The top 10 smart cities on the planet. [Accessed 12 March 2021]. https://www. fastcodesign.com/1679127/the-top-10-smart-cities-on-the-planet.

Daniere A \& Douglass M (2009) The Politics of Civic Space in Asia: Building Urban Communities. London: Routledge.

Dinas Pekerjaan Umum Bina Marga dan Pematusan (2015) Pemerintah Kota Surabaya: Dinas Pekerjaan Umum Bina Marga dan Pematusan. [Accessed 14 March 2021]. https://www.surabaya.go.id/id/ page/0/8075/dinas-pekerjaan-umum-bina-marga-dan-pematusan.

Duneier M (1999) Sidewalk. New York: Farrar, Strauss and Giroux.

Efendi Z (2018) Seberapa panjang saluran dan pedestrian telah dibangun di Surabaya? detikNews, 14 August. [Accessed 14 March 2021]. https://news.detik.com/berita-jawa-timur/d-4165781/ seberapa-panjang-saluran-dan-pedestrian-telah-dibangun-di-surabaya.

Ehrenfeucht R \& Sideris LA (2007) Constructing the sidewalks: Municipal government and the production of publik space in Los Angeles, California, 1880-1920. Journal of Historical Geography 33 (1):104-124. https://doi.org/10.1016/j.jhg.2005.08.001.

Given LM (2008) The Sage Encyclopedia of Qualitative Research Methods 1\&2. California: Sage Publication.

Goldstein DM (2016) Owners of the Sidewalk: Security and Survival in the Informal City. Durham: Duke University Press.

Harvey D (2008) The right to the city. New Left Review 53:23-40.

Jacobs J (1961) The Death and Life of Great American Cities. New York: Random House.Inc.

Keymolen E \& Voorwinden A (2019) Can we negotiate? Trust and the rule of law in the smart city. International Reiview of Law, Computers and Technology 34 (3):1-21.

Kim AM (2015) Sidewalk City: Remapping Publik Spaces in Ho Chi Minh City. Chicago: University of Chicago Press.

Lefebvre H (1967) "The Right to the City" And "Theses on the City, the Urban and Planning". In: Kofman E. \& Lebas E. (ed). Writing on Cities-Henri Lefebvre. Oxford: Blackwell.

Lefebvre H (1991) The Production of Space. Trans. by Donald Nicholson-Smith. Cambridge: Blackwell.

Lefebvre H (1996) The Right to the City. In: Kofman, Eleonore; Lebas, Elizabeth (ed). Writings on cities. Cambridge, Massachusetts: Wiley-Blackwell.

Locton DJ (2011) Architecture, urbanism, design and behaviour: A brief review. [Accessed 2 February 2018]. https://www.researchgate.net/publikation/260752108.

Low S \& Smith N (2006) The Politics of Publik Space (1 $1^{\text {st }}$ ed). NewYork: Rouletdge.

MadanipourA, Knierbein S, \& Degros A(2013) Publik Space and the Challenges of Urban Transformation in Europe. New York: Routledge. 
McCord C \& Becker C (2019) Sidewalk and Toronto: Critical Systems Heuristics and the Smart City. New York: Cornell University.

Mehta V (2013) The Street: A Quintessential Social Publik Space. New York: Routledge.

Nagati O \& Stryker B (2016) Street Vendors and the Contestation of Publik Space. Spanyol: Cluster. [Accessed 4 February 2018]. http://www.wiego.org/publikations/street-vendors-and- contestationpublik-space.

Pemerintah Kota Surabaya (2018) Daftar nama jalan dan status jalan di Kota Surabaya. [Accessed 14 March 2021]. https://www.surabaya.go.id/id/berita/49774/daftar-nama-jalan-dan-status-ja.

Repko J \& DeBroux S (2012) Smart cities literature review and analysis. [Accessed 5 January 2018]. https://www.researchgate.net/publication/236685572.

Soja EW (2010) Seeking Spatial Justice. Minneapolis: University of Minnesota Press.

Van Deusen RP (2002) Space design as class warfare: Urban design, the 'right to the city' and the production of Clinton Square, Syracuse, NY. GeoJournal 58:149-158. https://doi.org/10.1023/ B:GEJO.0000010834.17907.5e.

Von Schonfeld, Kim C, \& Bertolini L. (2016) Urban streets between publik space and mobility. Transportation Research Procedia 19:300-302. https://doi.org/10.1016/j.cities.207.04.012.

White WH (2001) The Social Life of Small Urban Spaces. Maryland: Toxado.

Winkowska J, Szpilko D, \& Sonja P (2019) Smart city concept in the light of the literature review. Engineering Management in Production and Services 11 (2). https://doi.org/10.2478/emj-20190012 . 